УДК: $61: 651.928: 681$. 3І: $003.26: 681.31: 007$

\title{
МАТЕМАТИЧНІ АЛГОРИТМИ ЗАХИСТУ ІНФОРМАЦІЇ
}

І. М. Шупяцький

Аержавна служба спеціального зв'язку та захисту інформації України

У статті проаналізовано математичні алгоритми захисту інформації з метою використання методології алгоритму криптографії в медицині.

Ключові слова: криптографія, алгоритм, ключ, методологія.

\section{МАТЕМАТИЧЕСКИЕ АЛГОРИТМЫ ЗАЩИТЫ ИНФОРМАЦИИ}

\author{
И. М. Шупяцкий \\ Государственная служба специальной связи и защиты информации Украины \\ В статье проанализированы математические алгоритмы защиты информации с целью использования методо- \\ логии алгоритма криптографии в медицине.
}

Ключевые слова: криптография, алгоритм, ключ, методология.

\section{MATHEMATICS ALGORITHMS OF THE INFORMATION PROTECTION}

\author{
I. M. Shupiatskyi \\ State department of the special connect \& protection information of Ukraine
}

\begin{abstract}
There were discussed mathematics algorithms of the information protection with purpose to use the main methods of the cryptography algorithm in the medicine.
\end{abstract}

Key words: cryptography, algorithm, key, main methods.

Присвячується 120-річчю засновника сучасних математичних методів криптографії, академіку АН УРСР М. П. Кравчуку.

Вступ. На сьогодні захист інформації здійснюється за допомогою та на основі сучасних техніко-економічних криптографічних засобів. Медична інформація це інформація конфіденційна, яка потребує цілеспрямованого захисту, захисту криптографічного в сучасному інформаційному просторі. Мета захисту - недопущення використання медичної інформації особами, які не мають права доступу до конфіденційних ресурсів.

Одним із основних методів сучасних криптографічних алгоритмів є прикладна теорія чисел, яка $є$ фундаментом сучасних математичних криптографічних алгоритмів. При обміні інформацією між учасниками часто виникає ситуація, коли інформація не є конфіденційною, а саме, - отримання повідомлень у неперекрученому вигляді і наявність гарантії, що ніхто не в змозі підробити повідомлення.

Мета роботи полягає в проведенні аналізу математичних алгоритмів захисту інформації для можли- востей використання методології алгоритму криптографії в медицині.

Отримані результати та їх обговорення. Криптосистеми із секретним ключем (одноключові, симетричні або класичні), а також криптосистеми з відкритим ключем (асиметричні) максимально адаптовані до використання з метою захисту і збереження інформації. Як приклад можна навести основні положення криптологічного протоколу "електронний підпис".

Математична криптографія виникла як наука про шифрування інформації, - як наука про криптосистеми.

Криптосистема без передачі ключів.

Абоненти А, В, С, ... домовились організувати закрите листування між собою. Для цього вони вибрали достатньо велике просте число р і таке, що р-1 добре розкладається на не дуже великі прості множники. Якщо серед множників такого числа кратних немає, то число р-1 називають Евклідовим. Кожний з абонентів, незалежно один від одного, вибирає випадкове число, натуральне, взаємно просте з числом p-1: A, В, С, ... - абоненти; а, b, с, ... - вибрані ними 
випадкові числа. В подальшому абонент А знаходить число $\alpha$ змов

$\mathrm{a} \cdot \alpha \equiv 1(\bmod \phi(\mathrm{p})), 0<\alpha<\mathrm{p}-1$;

абонент В знаходить число в 3 умови

$\mathrm{b} \cdot \beta \equiv 1(\bmod \phi(\mathrm{p})), 0<\beta<\mathrm{p}-1$,

де ф(р) - функція Ейлера, a, $\alpha$ - закриті ключі абонента A; b, $\beta$ - закриті ключі абонента В тощо.

У тому випадку, коли абонент А вирішує надіслати повідомлення т абоненту В можна прогнозувати, що $0<\mathrm{m}<\mathrm{p}-1$. Тоді він спочатку зашифровує це повідомлення своїм першим закритим ключем, знаходить:

$\mathrm{m}_{1} \equiv \mathrm{m}^{\mathrm{a}}(\bmod \mathrm{p}), 0<\mathrm{m}_{1}<\mathrm{p}$

і направляє абоненту В. Абонент В, в свою чергу, зашифровує знову це повідомлення також своїм першим ключем:

$\mathrm{m}_{2} \equiv \mathrm{m}_{1}{ }^{\sigma}(\bmod \mathrm{p}), 0<\mathrm{m}_{2}<\mathrm{p}$

і пересилає його у зворотному напрямку абоненту А. Абонент А, отримавши своє подвійно зашифроване повідомлення, шифрує його ж втретє своїм другим ключем:

$\mathrm{m}_{3} \equiv \mathrm{m}_{2}^{\alpha}(\bmod \mathrm{p}), 0<\mathrm{m}_{3}<\mathrm{p}$

і знову відправляє його абоненту В. Останній розшифровує цю шифротелеграму за допомогою свого другого ключа:

$\mathrm{m}_{4} \equiv \mathrm{m}_{3}^{\beta}(\bmod \mathrm{p}), 0<\mathrm{m}_{4}<\mathrm{p}$.

Таким чином, з порівняння (3) - (4) маємо:

$\mathrm{m}_{4} \equiv \mathrm{m}^{\mathrm{k}}(\bmod \mathrm{p})$,

де $\mathrm{k} \equiv \mathrm{a} \cdot \alpha \cdot \mathrm{b} \cdot \beta(\bmod \mathrm{p}-1)$.

В силу (1) $\mathrm{i}(2) \mathrm{k} \equiv 1(\bmod \phi(\mathrm{p}))$. Тому $\mathrm{n}_{4} \equiv \mathrm{m}(\bmod \mathrm{p})$ a так як кожне 3 них позитивне i менше $\mathrm{p}$, то $\mathrm{T}_{4}=\mathrm{T}$.

Наприклад, нехай абоненти А і В вирішили встановити між собою прихований зв'язок без передачі ключів. Вони вибрали для цього просте число $\mathrm{p}=$ 9551. Тоді p-1=9550.

Абонент А вибирає випадкове число $\alpha=8159$, а абонент В - $b=7159$. Абонент А вирішує рівняння: $8159 \cdot \alpha \equiv 1(\bmod \phi(9551)), 0<\alpha<9550$ й знаходить $\alpha=$ 6639, а абонент В вирішує рівняння: $7159 \beta \equiv 1(\bmod$ $\phi(9551)), 0<\beta<9550$ й знаходить $\beta=6139$.

Абонент А вирішує надіслати секретне повідомлення абоненту В т=7032. Тоді він спочатку шифрує повідомлення своїм першим ключем: $\mathrm{m}_{1} \equiv \mathrm{m}^{\mathrm{a}}(\bmod \mathrm{p})=$ $7032^{81593}(\bmod 9551)=153$.

Абонент В, отримавши це повідомлення, шифрує його своїм першим ключем: $\mathrm{m}_{2} \equiv \mathrm{m}_{1}{ }^{\mathrm{b}}(\bmod \mathrm{p})=$ $153^{7159}(\bmod 9551)=4896$, і пересилає його абоненту
А, який, отримавши зашифроване повідомлення, шифрує його ж в третій раз своїм другим ключем: $\mathrm{T}_{3}{ }^{\circ} \mathrm{T}_{2}{ }^{\mathrm{a}}$ ( т о а p $)=4896^{6639}($ тоа 9551)=7577 і відправляє його абоненту $\mathrm{B}$, який розшифровує цю шифротелеграму за допомогою свого другого ключа: $\mathrm{T}_{4}{ }^{\circ} \mathrm{T} /($ т о а p $)=7577^{6139}($ тоа 9551 $)=7032$.

Розглянемо схожий приклад, але 3 великими числами, а саме нехай абоненти А і В вибирають випадкове число $\mathrm{p}=3 \quad 6185027886661311069$ 86593281521497120414687020801267626233049500 247285301313. Далі абонент А вибирає випадкове число $\mathrm{a}=32910091146424120843099383651147010$ 09965471731267159726697218119 , а абонент В- b=7 2133456729194312009114642445656781208430 93464793836516545465843 . АбонентА вирішує рівняння: 3291009114642412084309938365114701009965 $471731267159726697218119-\mathrm{a}^{\circ} 1$ (тоа ф(361850278 866613110698659328152149712041468702080 $1267626233049500247285301313)), 0<\mathrm{a}<3618502788$ 666131106986593281521497120414687020801267626 233049500247285301312 і знаходить $\mathrm{a}=7182890$ 94672427671226754071206041429575840582862 2569613369504272231654775 , а абонент В вирішує рівняння: 72133456729194312009114642445656781 $20843093464793836516545465843-$ p $^{\circ} 1$ ( тоа ф(119726 214130147567059245861496117904970213993920 59391)), $0<\mathrm{p}<1197262141301475670592458614961179$ 0497021399392059390 і знаходить $\mathrm{p}=205078500$ 8947982616772154473648909901784058010689679 595249365486507640220987.

Абонент А вирішує надіслати секретне повідомлення абоненту В $\mathrm{T}=1643953085623702335973$ 4047455621923453212389086. Тоді він с початку шифрує повідомлення своїм першим ключем: $\mathrm{T}_{1}{ }^{\circ} \mathrm{m}^{\mathrm{a}}(\mathrm{mod}$ $\mathrm{p})=1643953085623702335973404745562192345321$ 238900863291009114642412084309938365114701009965 ${ }^{4} 7^{1} 73^{12} 67^{1} 597^{2} 6697^{21} 8^{11} 9(\bmod \quad 36185027886661311069865$ 93281521497120414687020801267626233049500247285 $301313)=23404884717260896071245567562641693$ 38202290949701335616973062664572414115995.

Абонент В, отримавши це повідомлення, шифрує його своїм першим ключем: $\mathrm{m}_{2}{ }^{\circ} \mathrm{m}_{1}{ }^{\mathrm{a}}(\bmod \mathrm{p})=$ 2340488471726089607124556756264169338202290949 70133561697306266457241411599572133456729194312009114642445656781208430934 ${ }^{64793836516545465843}(\bmod \quad 36185027886661311069865$ 9328152149712041468702080126762623304950024728 $5301313)=200847152309106133691890020899385$ $1807662985672512619192514870979350742436070, \mathrm{i}$ пересилає його абоненту А. Абонент А, отримавши зашифроване повідомлення, шифрує його ж в третій раз своїм другим ключем: $\mathrm{m}_{3}{ }^{\circ} \mathrm{m}_{2}{ }^{\mathrm{a}}(\bmod \mathrm{p})$ 
$=20084715230910613369189002089938518076629$ $85672512619192514870979350742436070^{7182890}$ $9467242767122675407120604142099575840582862256961336950427231654775(\mathrm{mod}$ 361850278866613110698659328152149712041468 $7020801267626233049500247285301313)=337426795$ 6066404491443963921356203649 752330364752225196611392536160948437196 i відправляє у зворотньому напрямку його абоненту $\mathrm{B}$, котрий розшифровує цю шифротелеграму за допомогою свого другого ключа: $\mathrm{m}_{4}{ }^{\circ} \mathrm{m}_{3}{ }^{\mathrm{b}}(\bmod \mathrm{p})=$ 33742679560664044914439639213562036497523 $30364752225196611392536160948437196^{20507850089479}$ 82616772154473648909901784058010689679595249365486507640220987 $(\bmod 3618502788666131106986593281521497120414$ $687020801267626233049500247285301313)=$ 16439530856237023359734047455621923453212389086

Прикладом можуть служити паперові купюри. Як що ресурсом $€$ деякий товар, то наявність у покупця достатньої кількості купюр є доказом його права на доступ до ресурсу. 3 іншої сторони, хоча кожна паперова купю-

\section{Література.}

1. Анализ современных зарубежных систем защиты информации / под ред. $B . \Phi$. Колчина. // Обозрение прикл. и промышл. матем. - 2000. - Т. 7.

2. Вероятностно-статистический анализ последовательностей над конечным алфавитом / под ред. В. Г. Михайлова, B. П. Чистякова. // Обозрение прикл. и промышл. матем. - 1995. - T. 2.

3. Конечные автоматы: прообразы выходных последовательностей над конечным алфавитом / под ред. B. $Г . M u$ хайлова, В. П. Чистякова. //Обозрение прикл. и промышл. матем. - 1995. - Т. 1.

4. Методы дискретной теории вероятностей / под ред. A. M. Зубкова. // Обозрение прикл. и промышл. матем., 1996, т. 3. в. 4.

5. Новые подходы к решению вероятностных задач. Под ред. A. М. Зубкова. // Обозрение прикл. и промышл. ма- ра і має унікальний номер, відслідкувати купюри за номерами та виявити, хто ії використав і в яких платежах, практично неможливо.

Висновки. 1. Для запобігання загрозі контролю за джерелами інформації (звідки пересилаються повідомлення) необхідна система контролю за доступом до ресурсів, яка повинна задовольняти двом, здавалося б, взаємно протилежним потребам.

2. Кожен бажаючий повинен мати можливість звернутися до цієї системи анонімно, при цьому все ж довівши своє право на доступ до ресурсів.

3. Якщо задача забезпечення конфіденційності вирішується за допомогою криптосистем, то для забезпечення цілістності і унеможливлення відслідковування розробляють криптографічні протоколи. Адаптація криптографічних алгоритмів до телемедицини дасть можливість впровадження нових наукових та практичних досягнень, продуктом яких слід очікувати телемедичний алгоритм в криптографії, де основою $є$ поліном М. П. Кравчука.

тем.. - 1994. - Т. 1, В. 4.

6. Пороговая логика и нейрокомпьютеры. / под ред. Г. В. Балакина. //Обозрение прикл. и промышл. матем. 1994. - Т.1, В. 3.

7. Браун П. Приватность в век терабайтов и терроризма / Питер Браун // В мире науки. - 2008. - №> 12. - С. 20-21.

8. Ванчаков Н. Б. Практические основы защиты информации. Технические методы и средства : производственно практическое издание / Н. Б. Ванчаков, А. Н. Григорьев.Калининград : КЮИ МВД России, 2000. - 198 с.

9. Голубев Д. Л. Распределенные центры обработки данных / Голубев Д. Л. // Jet Info. - 2006. - №> 5. - С. 3-16.

10. Горбатов В. С. Основы технологии РКІ / В. С. Горбатов, О.Ю. Полянская. - М. : Горячая линия - Телеком, 2004 $246 \mathrm{c}$. 